\title{
PENGUKURAN BEBAN KERJA KARYAWAN DALAM MENGANGKAT TBS DENGAN PENDEKATAN ERGONOMI DI PT INCASI RAYA MUARA SAKAI
}

\author{
Tri Ernita ${ }^{1}$ \\ ${ }^{1}$ Program Studi Teknik Industri Sekolah Tinggi Teknologi Industri (STTIND) Padang \\ email: triernita@yahoo.com
}

\begin{abstract}
PT Incasi Raya is one of the companies engaged in industry palm oil. The production of palm oil is mostly exported to all over the world market. The number of requests from the world market, then the company should be able to optimize the available manpower to meet demand.This study aims to determine the percentage of employees' workload of the heart's workload seen in the lifting of fresh fruit bunches using CVL method, analyze the position of the employee in the lift FFB whether in accordance with ergonomic approach. Data were analyzed quantitatively using the method of CVL (Cardiovascular load) by analyzing the positions of employees in lifting the fresh fruit bunches.Based on the results of the research, the percentage of employees receiving workload CVL biggest heart in block $A$ with an average of $39.804 \%$ and the percentage of employees receiving CVL smallest cardiac workload on the block $E$ with an average of $25.976 \%$ and the employee's position in the lifting of fresh fruit bunches into the dump the truck is not ergonomic.
\end{abstract}

Keywords: Palm Oil, Workload, Ergonomics, Cardiovascular Load.

\section{PENDAHULUAN}

PT Incasi Raya merupakan salah satu perusahaan yang bergerak di industri minyak sawit. Hasil produksi minyak sawit ( CPO ) sebagian besar diekspor ke seluruh pasar dunia. Banyaknya permintaan dari pasar dunia, maka perusahaan harus dapat mengoptimalkan tenaga kerja yang tersedia untuk memenuhi permintaan. Selama ini, perusahaan kurang memperhatikan keluhankeluhan karyawan dalam mengangkat TBS kedalam dump truk. Adapun keluhan-keluhan yang dirasakan karyawan diantaranya keluhan pada bagian tubuh setelah melakukan pekerjaan, seperti timbulnya rasa sakit, nyeri dan ngilu, upah yang tidak sesuai dengan pekerjaan yang dilakukan, banyaknya TBS yang tidak bisa diangkat oleh karyawan kedalam dump truk, kondisi jalan yang tidak memadai dan upah kerja yang tidak sesuai dengan pekerjaan yang dilakukan. Dengan banyaknya keluhan-keluhan yang dirasakan karyawan dalam mengangkat TBS menyebabkan karyawan tidak betah mengangkat TBS ke dalam dump truk, dan memilih melakukan pekerjaan lain. sehingga mengakibatkan TBS sering terlambat di angkat ke pabrik.

Memperhatikan uraian diatas maka dapat dirumuskan masalah yang melatarbelakangi penelitian ini yaitu Berapakah persentase beban kerja karyawan dilihat dari beban kerja jantung dalam mengangkat TBS menggunakan metoda CVL dan Apakah posisi kerja karyawan dalam mengangkat TBS telah sesuai dengan pendekatan secara ergonomic.

Adapun tujuan dari penelitian ini adalah untuk menentukan persentase beban kerja karyawan dilihat dari beban kerja jantung dalam mengangkat TBS menggunakan metoda CVL dan menganalisa posisi kerja karyawan dalam mengangkat TBS apakah telah sesuai dengan pendekatan secara ergonomi.

\section{METODA PENELITIAN}

Jenis penelitian yang digunakan adalah penelitian deskriptif kuntitatif yaitu suatu penelitian yang bertujuan untuk mendeskripsikan atau memberikan gambaran 
yang lebih detail mengenai suatu gejala dan merubahnya menjadi data yang berwujud angka. Penelitian ini dilakukan pada PT Incasi Raya yang berlokasi di kenagarian Teluk Ampalu Kecamatan Pancung Soal Kabupaten Pesisir Selatan Propinsi Sumatera Barat.

Langkah-langkah yang dilakukan dalam penelitian ini yaitu:

1. Menentukan beban kerja dengan metoda CVL (cardiovascular load)

Menentukan klasifikasi beban kerja berdasarkan peningkatan denyut nadi kerja yang dibandingkan dengan denyut nadi maksimum yang dinyatakan dalam beban kardiovaskular (\% CVL). Beban kardiovasekuler (\% CVL) ini dihitung dengan rumus (Manuaba \& Vanwonterghem.1996 ):

$\% \mathrm{CVL}=$

Denyut Nadi Kerja - Denyut Nadi Istirahat $x 100 \%$ (Denyut Nadi Maksimum) - Denyut Nadi Istirahat

dengan keterangan, denyut nadi maksimum $=220-$ umur.

\section{Menganalisa posisi kerja karyawan secara ergonomi}

Dalam menganalisa posisi kerja karyawan dalam mengangkat TBS kedalam dump truk, dengan langkah-langkah sebagai berikut :

1. Mengambil satu sampel karyawan pada masing-masing blok, mulai dari blok A sampai blok F.

2. Mengidentifikasi data karyawan, dimana dengan mengetahui umur masing-masing karyawan.

3. Melihat cara kerja karyawan dalam mengangkat TBS kedalam dump truk.

4. Menanyakan keluhan-keluhan yang dirasakan karyawan setelah mengangkat TBS kedalam dump truk sampai selesai.

5. Memberikan kesimpulan dan saran.

\section{HASIL PENELITIAN DAN PEMBAHASAN}

Menentukan klasifikasi beban kerja berdasarkan peningkatan denyut nadi kerja yang dibandingkan dengan denyut nadi maksimum yang dinyatakan dalam beban kardiovaskular (\% CVL).
Hasil pengukuran persentase CVL pada karyawan yang bekerja pada blok A sampai blok F dapat dilihat pada Tabel 1.

Tabel 1. Rekapitulasi Hasil Pengukuran Persentase CVL Karyawan

\begin{tabular}{|l|c|c|c|c|}
\hline No & $\begin{array}{c}\text { Nama } \\
\text { Karyaw } \\
\text { an }\end{array}$ & $\begin{array}{c}\text { Usia } \\
\text { (Th) }\end{array}$ & $\begin{array}{c}\text { Bekerja } \\
\text { Pada Blok }\end{array}$ & $\begin{array}{c}\text { Rata- } \\
\text { rata } \\
\% \\
\text { CVL }\end{array}$ \\
\hline 1 & Warto & 46 & A & 39,804 \\
\hline 2 & Budi & 27 & A & 30,457 \\
\hline 3 & Anto & 30 & B & 30,786 \\
\hline 4 & Juli & 32 & B & 32,710 \\
\hline 5 & Isal & 25 & C & 28,848 \\
\hline 6 & Doni & 35 & C & 33,519 \\
\hline 7 & Jono & 34 & D & 33,667 \\
\hline 8 & Peki & 25 & D & 26,431 \\
\hline 9 & Pikal & 40 & E & 36,616 \\
\hline 10 & Ari & 24 & E & 25,976 \\
\hline 11 & Hendra & 23 & F & 26,081 \\
\hline 12 & Dayat & 38 & F & 35,492 \\
\hline
\end{tabular}

Dalam pangangkatan TBS (Tandan Buah Segar) kedalam dump truk, anatomi tubuh karyawan yang terlibat langsung dalam mengangkat TBS (Tandan Buah Segar) tersebut diantaranya :

a. Telapak tangan

Telapak tangan digunakan dalam mengangkat TBS kedalam dump truk adalah untuk memegang langsung peralatan toyak. Dengan memegang toyak yang cukup lama dan memiliki beban telapak tangan menjadi kasar dan akan melepuh kemudian membengkak.

b. Pergelangan tangan.

Dalam anatomi, pergelangan tangan adalah yang fleksibel dan sempit sambungan antara lengan bawah dan telapak tangan. Karyawan dalam mengangkat TBS kedalam dump truk menggunakan alat yang dinamakan atau disebut toyak. Alat toyak ini dipegang oleh tangan, untuk menggerakkan alat ini dibantu oleh pergelangan tangan. Pergelangan tangan akan menyesuaikan dengan kondisi peralatan, dimana pergelangan tangan akan berputar kekiri, kekanan, keatas dan kebawah. Seringnya pergelangan tangan berputar dan tidak pada posisi yang alamiah lama kelamaan pergelangan akan mengalami sakit dan akhirnya akan terkilir. 
c. Lengan

Lengan berperan penting dalam proses pengangkatan TBS kedalam dump truk, dimana lengan menjadi sumber kekuatan utama untuk menancapkan toyak ke TBS dan sebagai kekuatan untuk mengangkat TBS ke dalam dump truk nantinya.

d. Bahu

Setelah TBS diangkat dengan kekuatan pada lengan, maka untuk menahan berat TBS dibantu oleh bahu karyawan. Dimana bahu digunakan untuk menopangkan tangkai toyak dan setelah posisi tubuh karyawan dirasa cukup stabil lengan kembali berfungsi melemparkan TBS ke dalam dump truk sehingga TBS akan lepas dari toyak dan masuk ke dalam dump truk.

e. Punggung

Punggung berperan penting pada saat kekuatan lengan menancapkan toyak ke TBS, dimana punggung akan membungkuk mengikuti gerakan toyak yang ditancapkan ke TBS. punggung akan kembali keposisi tegak lurus saat TBS akan dilemparkan kedalam dump truk.

f. Pinggang

Pinggang sebagai tumpuan untuk menahan berat beban TBS dan pinggang juga akan mengatur punggung dalam meyesuaikan posisi toyak dalam menancapkan ke TBS.

Adapun pangangkatan TBS (Tandan Buah Segar) kedalam dump truk dapat terlihat pada gambar berikut ini :



\section{KESIMPULAN}

Berdasarkan pembahasan mengenai pengukuran beban kerja karyawan dalam mengangkat TBS di PT. Incasi Raya maka dapat ditarik kesimpulan beberapa kesimpulan sebagai berikut :

1. Dari hasil metoda CVL, persentase CVL karyawan menerima beban kerja jantung terbesar pada blok A dengan rata-rata 39,804\% dan persentase CVL karyawan menerima beban kerja jantung terkecil pada blok E dengan rata-rata $25,976 \%$.
Perbedaan ini terlihat jelas pada usia karyawan, dengan semakin bertambahnya usia karyawan semakin mudah pula karyawan merasakan kelelahan.

2. Berdasarkan hasil analisis secara subyektifis posisi kerja karyawan dalam mengangkat TBS kedalam dump truk tidak ergonomi, dimana terdapat keluhankeluhan yang dirasakan pada karyawan saat dan setelah mengangkat TBS ( Tandan Buah Segar ). Keluhan yang paling dirasakan oleh karyawan pada bagian bahu dan pinggang.

\section{KEPUSTAKAAN}

Ervil, Riko, dkk, Buku Panduan Penulisan dan Ujian Skripsi. Sekolah Tinggi Teknologi Industri (STTIND), Padang, 2014.

Kilbon, A. Measurement and Assessment of Dynamic Work. Dalam: Tarwaka, Bakri, S., Sudiajeng, L. 2004. Ergonomi untuk Keselamatan, Kesehatan Kerja dan Produktivitas. Surakarta: UNIBA Press. 102. 1992.

Manuaba, A \& Vanwonterghem, K, Improvement of Quality of Life. Determination of Exposure Limits for Physical Strenuous Jobs under Tropical Conditions. Final Report- CT-90019. Commission of the European Union. 1996.

Murrel, K.F.H.,. Human Performance in Industry. Dalam: Tayyari, F. \& Smith, J.L. Occupational Ergonomics: Principles and applications. London: Chapman \& Hall. 1965. 1997

Sugiyono, Metode Penelitian Kuantitatif Kualitatif dan R\&D, Alfabeta, Bandung, 2011.

Tayyari, F. \& Smith, J.L., Occupational Ergonomics: Principles and applications. London: Chapman \& Hall. 1997.

Tarwaka, Bakri, S., Sudiajeng, L. Ergonomi untuk Keselamatan, Kesehatan Kerja dan Produktivitas. Surakarta: UNIBA Press. 2004.

Widodo, S. Penentuan Lama Waktu Istirahat Berdasarkan Beban Kerja dengan Menggunakan Pendekatan Fisiologis (Studi Kasus pada Pabrik Minyak Kayu Putih Krai, Jawa Tengah), Skripsi, Universitas Muhammadiyah Surakarta. 2008. 